\title{
Physiotherapy Intervention According to the Bobath Concept in a Clinical Case of Cerebral Palsy
}

\author{
Gustavo Desouzart* \\ Research in Education and Community Intervention, Portugal \\ *Corresponding author: Gustavo Desouzart, Research in Education and Community Intervention, Portugal
}

Submission: 眥 December 21, 2017; Published: 望笽 July 03, 2018

\begin{abstract}
Cerebral Palsy (CP), according to Richards \&Malouin [1], consists of chronic non-progressive encephalopathy resulting from a Central Nervous System (CNS) lesion manifested by disorders of movement, posture, balance and coordination, with the variable presence of voluntary movements. Some rehabilitation approaches that have been used in CP rehabilitation are the Bobath Concept, the task-specific training, and the family-centered approach. The aim of this study was to verify the influence of the physiotherapy intervention according to the neuro developmental techniques according to the bobath concept, in the improvement of global motor skills in a 36-month-old child with bilateral spastic cerebral palsy. For this purpose, the Gross Motor Function Measure (GMFM) evaluation scale was applied pre and post test ( 2 times a week for 12 weeks) and the main problems of the child according to the International Classification of Functionality (ICF) were classified. The results after the intervention, in which the same measurement and evaluation instruments were used, according to GMFM, showed a slight evolution, with child's gross motor capacities at the 18-month level. In overall terms, there is improvement in all components of the ICF, which is more marked in activities. After analyzing this case the results obtained were positive although they were not reached in their fullness.
\end{abstract}

Keywords: Physiotherapy intervention; Cerebral palsy; Bobath concept; Gross motor function measure; International classification of functionality

Abbreviations: CP: Cerebral Palsy; CNS: Central Nervous System; GMFM: Gross Motor Function Measure; ICF: International Classification of Functionality; NDT: NeuroDevelopment Techniques

\section{Introduction}

Cerebral Palsy (CP), according to Richards \&Malouin [1], consists of chronic non-progressive encephalopathy resulting from a Central Nervous System (CNS) lesion manifested by disorders of movement, posture, balance and coordination, with the variable presence of voluntary movements. It can be said that this is a static encephalopathy in which the primary lesion is not progressive; however, the clinical presentation pattern may change over time due to the growth and development of CNS maturation and plasticity [2].

The movement disorders present in CP are clinically characterized by upper motor neuron damage with changes in cortical circuits and absence of adequate sensor-motor control mechanisms. The motor cortex projections for the spinal motoneurons are altered, which causes difficulties in voluntary movement [1].One of the most common features is spasticity, a sensorimotor control disorder resulting from upper motor neuron injury. It is manifested by an increase of the reflex of passive muscle stretching, which intensifies with the speed of movement, that is, there is an inappropriate and excessive involuntary muscular activation. Spasticity is a dysfunction that can cause limitations of ADLs, such as walking, bathing, dressing, transfer and sitting / lifting difficulties. Other musculoskeletal consequences may also occur over time such as pain, deformities and dislocations $[3,4]$.

It is important to consider child neuropsychomotor development insofar as delays of this can be prolonged until adulthood. With regard to intervention, it has shown more benefits for children when the therapist's performance is associated with parental involvement[5].Some rehabilitation approaches that have been used in CP rehabilitation are the Bobath Concept, the taskspecific training, and the family-centered approach [1]. The most recent approaches shift the focus from disability intervention to promoting children's independence and participation [6].

\section{Case Presentation}

The present case is a 3-year-old male, with spastic paraparesis and delayed motor development. The child moves essentially on a cat and cannot walk alone, getting the activity with support but with much instability. To move around at home and in preschool often uses a previous walker. It also presents difficulties in some daily life activities (DLAs), such as dressing / undressing, underwear and bathing, in which the child tries to collaborate but does not perform 
the activity autonomously. The expectations of the child and the family for the intervention are to enable the child to be able to move alone and to be more autonomous in the DLAs.

The evaluation includes the collection of clinical and subjective data and the application of tests [7].For this purpose, the Gross Motor Function Measure (GMFM) evaluation scale was applied pre and post test ( 2 times a week for 12 weeks) and the main problems of the child according to the International Classification of Functionality (ICF) were classified, according to the clinical process and the survey of family needs and expectations (perspective of the condition, problems, expectations and contextual factors).

Considering the clinical condition of the patient resulting from a hypoxic ischemic PC injury, resulting in difficulties in postural control, balancing ability and intersegmental coordination, the intervention was developed with a view to the development of this same postural control, with the aim of improving the ability to balance and coordinate, ie through the transmission of stimuli to the CNS.An important factor to take into account in the intervention in these cases is the development of stabilization exercises of the trunk and the proximal muscles [8].

Rottaet al. [9] states that the different methods used in Physical Therapy are used according to the clinical picture, and the most commonly used approach to Neurodevelopment Techniques (NDT) is the Bobath Concept. Some of the studies $[10,11]$ have shown that the approach to TND of the Bobath concept is effective in improving motor performance measures in children with $\mathrm{CP}$, especially in global motor skills, postural control, and stability. Molenaers et al. [12] state that only studies using NDT seem to demonstrate a trend of efficacy at all levels of ICF.

\section{Results and Discussion}

GMFM is an instrument that assesses gross motor function, important for the child's functional performance, and is primarily intended for children with CP. Studies indicate that it allows to better target the objectives of the intervention as well as to determine the most appropriate techniques. The present case is classified as Level III, that is, it is using an auxiliary locomotion device. At the baseline, the results of GMFM showed a moderate delay in motor development, since gross motor capacities place the child between 12 and 18 months, when in fact 36 months. Despite the advantages of its use, the GMFM does not measure the quality of the child's activities, so the association with the ICF allows this to be addressed $[7,13,14]$.

The results after the intervention, in which the same measurement and evaluation instruments were used, according to GMFM, showed a slight evolution, with child's gross motor capacities at the 18-month level. In overall terms, there is improvement in all components of the ICF, which is more marked in activities (Table 1).

Table 1: Pre and post test results according to GMFM and ICF.

\begin{tabular}{|c|c|c|c|c|}
\hline Measured Instrument & Domain & Pre-Test & Purpose & Post-Test \\
\hline \multirow{6}{*}{ GMFM } & A. Decubits and rotate & $96,1 \%$ & $100 \%$ & $100 \%$ \\
\hline & B. Sit & $95 \%$ & $100 \%$ & $98,3 \%$ \\
\hline & C. Crawling and kneeling & $85,7 \%$ & Maintain or improve & $92,9 \%$ \\
\hline & D. Standing position & $56,4 \%$ & $75 \%$ & $61,5 \%$ \\
\hline & E. Walking, running, and jumping & $19,4 \%$ & $40 \%$ & $20,8 \%$ \\
\hline & Total & $70,52 \%$ & $75 \%$ & $75 \%$ \\
\hline \multirow{10}{*}{ ICF } & Joint mobility functions & b710.2 & b710.1 & b710.1 \\
\hline & Trunk muscle tone & b7355.3 & b7355.2 & b7355.3 \\
\hline & Crouch down & $\mathrm{d} 4101.3$ & $\mathrm{~d} 4101.1$ & $\mathrm{~d} 4101.1$ \\
\hline & Sit down & $\mathrm{d} 4103.2$ & d4103.1 & $\mathrm{d} 4103.1$ \\
\hline & Stand up & $\mathrm{d} 4104.3$ & $\mathrm{~d} 4104.1$ & $\mathrm{~d} 4104.1$ \\
\hline & Stand up & $\mathrm{d} 4154.2$ & $\mathrm{~d} 4154.1$ & $\mathrm{~d} 4154.1$ \\
\hline & Wash up & d510.2 & d510.1 & d510.2 \\
\hline & Dress-up/shorts & d540.3 & d540.1 & d540.1 \\
\hline & $\begin{array}{l}\text { Products and technologies for personal use in } \\
\text { daily life }\end{array}$ & e115.2 & e115.+1 & e115.+1 \\
\hline & Personal care providers and personal assistants & $\mathrm{e} 340 .+2$ & $\mathrm{e} 340 .+3$ & e340.+3 \\
\hline
\end{tabular}

After analyzing this case the results obtained were positive although they were not reached in their fullness. Regarding the intervention of Physiotherapy in the $\mathrm{CP}$ are several studies and techniques pointed out in the literature as beneficial, however, almost all the studies refer to the need for more research and quality[1,8,9,15-19]. 


\section{References}

1. Richards CL, Malouin F (2013) Cerebral palsy: definition, assessment and rehabilitation. Handb Clin Neurol 111: 183-195.

2. Zonta MB, Ramalho A, Santos LHC (2011) Avaliação funcional na paralisia cerebral. Acta Pediatr Port 42: 27-32.

3. Bar-On L, Molenaers G, Aertbeliën E, Campenhout VA, Feys H, et al. (2015) Spasticity and its contribution to hypertonia in cerebral palsy. Biomed Res Int 317047.

4. Shamsoddini A, Amirsalari S, Hollisaz MT, Rahimnia A, Aghda AK (2014) Management of spasticity in children with cerebral palsy. Iran J Pediatr 24(4): 345-351.

5. Willrich A, Azevedo CCF, Fernandes JO (2009) Desenvolvimento motor na infância: influência dos fatores de risco e programas de intervenção. Rev Neurocienc 17: 51-56.

6. Law M, Darrah J (2014) Emerging therapy approaches: An emphasis on function. J Child Neurol 29(8): 1101-1107.

7. Dornelas FL, Lambertucci MS, Mello ML, Deloroso FT (2014) Aplicabilidade da Classificação Internacional de Funcionalidade Incapacidade e Saúde (CIF) para a avaliação de crianças com paralisia cerebral: uma revisão sistemática/applicability of the international classification of functioning, disability and healt. Cad Ter Ocup da UFSCar 22(3).

8. Armutlu K (2010) Ataxia: physical therapy and rehabilitation applications for ataxic patients. Buffalo University, USA.

9. Rotta NT (2002) Paralisia cerebral: novas perspectivas terapêuticas. J Pediatr 78(Suppl 1): S48-S54.

10. Butler C, Darrah J (2001) Effects of neurodevelopmental treatment (NDT) for cerebral palsy: an AACPDM evidence report. Dev Med Child Neurol 43: 778-790.
11. Tsorlakis N, Evaggelinou C, Grouios G, Tsorbatzoudis C (2004) Effect of intensive neurodevelopmental treatment in gross motor function of children with cerebral palsy. Dev Med Child Neurol 46: 740-745.

12. Molenaers G, Calders P, Vanderstraeten G, Himpens E (2012) The evidence-base for conceptual approaches and additional therapies targeting lower limb function in children with cerebral palsy: a systematic review using the international classification of functioning, disability and health as a framework. J Rehabil Med 44(5): 396-405.

13. Pina LV, Loureiro APC (2017) O GMFM e sua aplicação na avaliação motora de crianças com paralisia cerebral. Fisioter em Mov 19(2).

14. Vasconcelos RLM, Moura TL, Campos TF, Lindquist ARR, Guerra RO (2009) Avaliação do desempenho funcional de crianças com paralisia cerebral de acordo com níveis de comprometimento motor. Brazilian J Phys Ther Bras Fisioter 13(5).

15. Aisen ML, Kerkovich D, Mast J, Mulroy S, Wren TAL, et al. (2011) Cerebral palsy: clinical care and neurological rehabilitation. Lancet Neurol 10(9): 844-852.

16. Dewar R, Love S, Johnston LM (2015) Exercise interventions improve postural control in children with cerebral palsy: a systematic review. Dev Med Child Neurol 57(6): 504-520.

17. Gama AC, Brianeze S, Cunha AB, Peviani SM, Miranda VCR, et al. (2009) Efeito de um programa de fisioterapia funcional em crianças com paralisia cerebral associado a orientações aos cuidadores: estudo preliminar. Fisioter e Pesqui 16(1): 40-45.

18. Martin L, Baker R, Harvey A (2010) A systematic review of common physiotherapy interventions in school-aged children with cerebral palsy. Phys Occup Ther Pediatr 30(4): 294-312.

19. Thomason P, Graham HK (2014) A systematic review of interventions for children with cerebral palsy: the state of the evidence. Dev Med Child Neurol 55(10): 885-910.

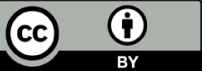

Creative Commons Attribution 4.0 International License

For possible submissions Click Here

\section{Submit Article}

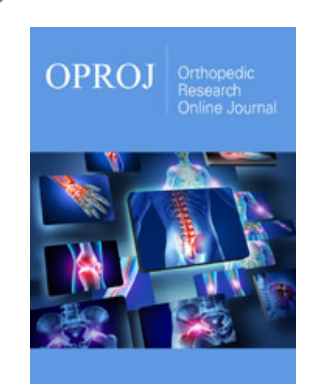

\section{Orthopedic Research Online Journal}

\section{Benefits of Publishing with us}

- High-level peer review and editorial services

- Freely accessible online immediately upon publication

- Authors retain the copyright to their work

- Licensing it under a Creative Commons license

- Visibility through different online platforms 